\title{
Educational Computer Software in the Function of Integrating and Individualization in Teaching of Mathematics and Knowledge of Nature
}

\author{
Milenko Ćurčić ${ }^{1}$, Dragica Milinković ${ }^{1 *}$, Dragana Radivojević ${ }^{1}$ \\ ${ }^{1}$ University of East Sarajevo, Bijeljina, Republic of Srpska, BOSNIA AND HERZEGOVINA \\ Received 2 February 2017 • Revised 30 May 2018 • Accepted 25 June 2018
}

\begin{abstract}
The paper examines the empirically verified effect (parallel group experiment) of the application of the software form of integration and individualization of teaching of natural and mathematical knowledge in relation to traditional teaching, for example, the teaching sub-themes Cultivated habitats and life communities, and Equations with addition, subtraction, multiplication and division in the set $\mathrm{N}$ (the natural numbers) and $\mathrm{N}_{0}$ (the natural numbers plus the neutral element 0 ). The sample consisted of 250 pupils aged 10 to 11 years: 125 in the experimental group and 125 in the control group. The data were processed by statistical procedures and displayed in textual and graphical ways. The statistical analysis of the data obtained from the research has been achieved by the SPSS 17.0 software package, wherein the arithmetic mean, standard deviation, a t-test. Statistical indicators have confirmed the assumptions that the software form of integration and individualization contributes to more efficient and easier acquiring of knowledge, raising the quality and quantity of students' knowledge and increasing the interest in studying content in the teaching of Knowledge of Nature and Mathematics, and as such points to a preferred model of teaching and learning.
\end{abstract}

Keywords: computer-assisted teaching, contemporary, integrated and individualized teaching, learning models, learning flexibility

\section{INTRODUCTION}

The development of science, technique and modern technology has changed all the spheres of society, so in the school system there was also a need for a more modern and active way of organizing the teaching process. One of the basic expectations of more rational and effective learning is the creation of situations in which the student will be at the center of the teaching process with the possibility of flexible adoption of the predicted content. As the most appropriate solution, the differentiation and individualization of teaching is emphasized, enabling each student to develop his/her, primarily, intellectual abilities.

\section{BACKGROUND OF THE STUDY}

The greatest benefits for individualized teaching in the junior primary school are provided by modern computer technology. Computerized interpretation of teaching content, on the one hand, enables a wider and more contented thinking process among students and a deeper and more thorough learning of educational content, and on the other, monitoring students' abilities and a pace by which the learner can master the curriculum envisaged.

Chaudhari (2013) highlights numerous benefits of computer-assisted teaching that are reflected in the following elements:

- The ability to learn at a personal pace: a pupil can learn content at a personal pace and repeat a task if he does not understand what he is learning.

(C) 2018 by the authors; licensee Modestum Ltd., UK. This article is an open access article distributed under the terms and conditions of the Creative Commons Attribution License (http://creativecommons.org/licenses/by/4.0/). $\square$ ljekobilje@teol.net $\square$ sadra@teol.net (*Correspondence) $\square$ dragan-r1@live.com 


\section{Contribution of this paper to the literature}

- Using the software form of integrating Mathematics and Knowledge of Nature teaching, students achieved significantly better quality and preserving knowledgein the whole as well as within the analyzed cognitive domains (knowledge, understanding and application).

- The somewhat greater progress of the experimental group in Mathematics is the result of learning Mathematics in the context, which, in the first place, reinforces mathematical understanding.

- This paper presents a contribution to the foundation of contemporary, integrated and individualized teaching of Mathematics and Knowledge of Nature, supported by educational computer software.

- Current feedback for pupils and teachers: fast feedback motivates students and determines further workflow and if the answer is not correct it will help correct his mistake.

- Automatically adjusting students' levels of competence: A computer-assisted program is designed in such a way that it can help both advanced students and students who have difficulty in mastering the material and that is what makes it flexible.

- Continuous interaction: computer-supported programs allow for continuous interaction.

- Flexibility of time: programs have flexibility in terms of time, place and pace of work.

Milinković and Pikula (2013) point out that computerization of teaching provides the most adequate response to the demand for the integrity of teaching in the junior primary school, which presupposes a didactic-methodical transformation of program contents in the direction of their connection and integration. With such work method, Pešikan and Ivić (2000) confirm, the subject-lesson system is exceeded, which is mostly a limiting factor in the regular schooling. An interdisciplinary approach to teaching contents is provided, that corresponds very clearly to active learning methods that emphasize the importance of forms of learning that encourage complex (and higher) mental processes such as creativity, linking knowledge, applying knowledge, independence, initiative, and the freedom of pupils to choose and express themselves. Jacobs defines interdisciplinary learning as "A knowledge view and curriculum approach that consciously applies methodology and language from more than one discipline to examine a central theme, issue, problem, topic, or experience" (Jacobs, 1989: 8). The concept of interdisciplinary education „recognizes the integrity and uniqueness of each subject area, but recognizes interrelations between subjects. An interdisciplinary approach in teaching is important because of the integrative process in science, which increasingly establishes the connections between certain scientific disciplines, which reflects the scientific and technological development of society and implies the team work of professionals of different profiles" (Rodić, 2014: 283). In the process of integration, emphasizes Walsh (2002), the role of teachers, who will apply the interdisciplinary educational model at the very beginning of schooling to enlighten students in terms of the interdependence of all parts of life is especially significant.

According to Milinković (2011) in the teaching of the mathematics of the basic school cycle, the teaching topics are based on the contextual problem of what is relevant for the students. In this process, special attention is paid to vertical and horizontal mathematization. The selected authentic context in each teaching unit initiates the introduction or application of mathematical concepts from different thematic areas and the establishment of links with other teaching subjects, or scientific disciplines.

The objective connection that exists between nature and Knowledge of Nature, must be dominantly represented in the cognitive process of learning the curriculum content of their subjects. When mathematical content in classroom is concerned, the most natural is the connection with the contents of nature and society that provide a very high quality basis for achieving interdisciplinary teaching and learning. In teaching the interdisciplinary approach in mathematics, Milinković (2013) emphasized that the complexity and comprehensiveness of the program of nature and society imply integrated topics from this teaching area, which are related to other educational areas without interfering with their relative autonomy and their own logic. This implies that already in the planning and programming of teaching work at the beginning of the school year, that is, when drafting an operational plan, the contents of nature and society must be firstly planned and analyzed in order to serve as a basis for planning the program contents of other subjects.

Deneme and Ada emphasize that "an interdisciplinary approach aims to bring teachers from different disciplines together in order to solve the problem of effective teaching. As they are aware of the levels and the needs of their students, they design their syllabus and materials accordingly. Integrating various disciplines can help children comprehend a topic which may lead to effective learning" (Deneme \& Ada, 2012: 886). However, Alghamdi (2017) pointed out that we should take care that such an approach to integration must be in line with the standards and outcomes that are specific for each subject area. 
The pursuit of subject interconnection, which arises from the need to increase the efficiency of pedagogical processes in all teaching subjects studied in basic education, was also analyzed by Curčić (2006). He pointed out that the connection of subjects, close to content, not only affects the quality of knowledge, but also helps prepare students for independent work and influences the formation of a scientific view of the world. In this context, educational computer software enables each individual to acquire the necessary knowledge in the mentioned field, while also having constant feedback on the success of the mastered material. Individualization of learning through educational computer software provides the pupil with the opportunity to become aware of learning goals, to master the strategies of studying, recognize the achieved goals and estimate the potentials for new accomplishments. One of the basic tasks of this kind of teaching is to ensure quality implementation of individualization and differentiation of teaching in teaching practice.

Grdinić and Branković (2005) state that individualization and differentiation provide: information designed and created in different ways; tasks for pupils that can be formulated and set up in different ways; supplementary information for pupils with lower previous knowledge and lower intellectual abilities; additional information for those pupils who wish to learn more about the material being taught. Educational computer software (ECS) enables day-to-day dosing of problems that attract the attention of pupils and "relieves" the teacher in terms of the number of hours since with this way of working the teacher will have as much time for his pupils as their interests dictate.

In the context of integration and interdisciplinary approach, in the recent years there is a tendency to enable students to educate in the field of Science, Technology, Engineering and Mathematics (STEM). The emergence of integrated STEM education in some institutions shows that this approach offers students better solutions to problems and develops logical thinking. Furner and Kumar point out the importance of integrated curriculum noting that "research indicates that using an interdisciplinary or integrated curriculum provides opportunities for more relevant, less fragmented, and more stimulating experiences for learner" (Furner \& Kumar, 2007: 186).

Backer and Park (2011) in the analysis of 28 studies examined the effects of integrative approaches among STEM subjects and came to the conclusion that the greatest effect is achieved at the elementary school level, and the lowest in college.

Deneme and Ada (2012) suggest that the benefits of using interdisciplinary approach in primary schools.

Kurt and Pehlivan (2013) having analyzed a number of studies that focus on the concept of integrated science and mathematics indicate that integration improves student achievement.

Tudor (2014) using the empirical research in primary school confirmed that creating lessons based on integration activities provides greater student achievement.

Alghamdi (2017) stated the positive examples from Saudi Arabia on the necessity and effectiveness of the integration of various scientific disciplines in order to improve the academic achievement of students.

Ćurčić, Milinković and Radivojević (2017) have investigated the effects of an interdisciplinary approach in primary school children in the case of integration with the teaching of mathematics and knowledge of nature and the student's responses to this model of learning. The results showed that students responded positively to this approach to teaching mathematics, indicating that a multidimensional approach to learning contributes significantly to a better understanding of the mathematical content and concepts as well as a better understanding of the contents in nature and society, and that significantly improves the quality of functional and applicable knowledge and motivation for learning in general.

\section{Software Model for Integration and Individualization in Teaching of Knowledge of Nature and Mathematics}

"Besides a wide variety of educational software that provide opportunities for teachers $t$ present their lessons (Niederhauser \& Stoddart, 2001) and increase student motivation (Lambić, 2011), development of information technology has enabled teachers to create their own (simple) educational software to meet their personal and their students' needs" (Lambić, 2014: 816).

Accordingly, an experimentally verified model of the ECS for the teaching subculture of Cultivated Habitats and Life Communities has been created from the Course of Knowledge of Nature and sub-theme of Equations with addition, subtraction, multiplication and division in the $N$ and $N_{0}$ Mathematics set.

The contents of mathematics in the given natural context were created for learning by introducing students into the process of mathematics of real situations from nature. In that sense, Milinković and Pikula (2014) emphasize that the "mathematical part" of software is determined by a realistic approach and contextualization of teaching, and a modeling method that mediates between the real environment and the "world" of mathematics in the process of solving "natural" problems.

Educational software designed for the purpose of research has been created in Microsoft Power Point. Software maintenance in this format will be easy to use on any computer without installing additional software, as well as 


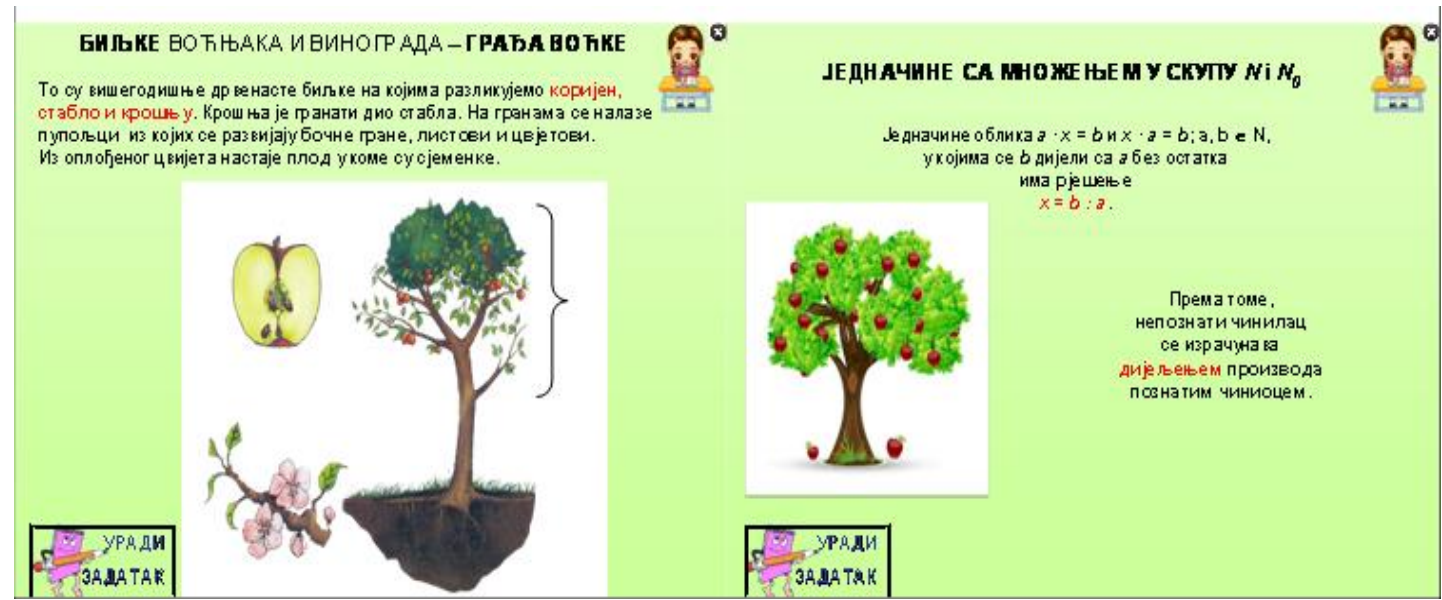

Figure 1. Interpretation of Content

high compatibility and use in various software and hardware environments. The whole written material in the software is adapted to the age of the students whom it is intended, written in Serbian language (mother tongue) and enriched with numerous illustrations, animations and videos.

The ECS is conceived as a presentation of a multimedial character whose goal, in an interesting, unusual and entertaining manner, presents students with the knowledge they need to acquire within the stated teaching areas. It is intended for adoption, expansion, training and repetition of fifth grade students' knowledge, and it is designed to provide the possibility of individual advancement. Individualization is enabled through several modules.

Content interpretation module (Figure 1) is achieved through the formation of basic and feedback information.

Since the basic text with the dominant informative function occupies a central place in the adoption of content by determining the extent of the material that pupils should adopt, it must be ensured that the content is logically structured, measured, reviewed, systematic and gradual, and in accordance with the expected goals and learning outcomes; Bearing in mind the differences between pupils, it began from a varied way of presenting the content being studied (text/real problem, image, animation, video ...), respecting the basic principles that, according to empirical research, Mayer (2009) established, and for the purposes of this research, the importance of multimedia: the student learns more successfully by using words and images, then by only using words; the principle of a spatial constraint that perceives the best effects of learning through the ability to present words and pictures one by one rather than when they are distant; Limited time principle which emphasizes more effective learning when words and images are displayed simultaneously; the principle of coherence by which more effective learning is achieved when the excessive (irrelevant) words, images and sounds are eliminated from the content; The principle of individual differences indicates that the effects of the design process are more effectively reflected on the pupils with lesser knowledge than on pupils with greater knowledge. The aim of interpreting content through multimedia systems is to get to know the complex processes and phenomena in cultivated habitats and life communities in the fastest, most obvious and most efficient way, and to form and solve equations with addition, subtraction, multiplication and division in the set $\mathrm{N}$ and $\mathrm{N}_{0}$. Depending on the priority of learning outcomes, content is also formed in feedback.

The Knowledge acquisition module (Figure 2) was realized through differentiation of task. Adaptation of questions and tasks to the teaching contents, expected outcomes and pupils' abilities was carried out on various issues and tasks, of the textual (alternative choice questions, questions of multiple choice, finding the appropriate pair, inserting expressions, concise answer) and graphic content (Venn diagram; grids, arrows, plain tables, images). 


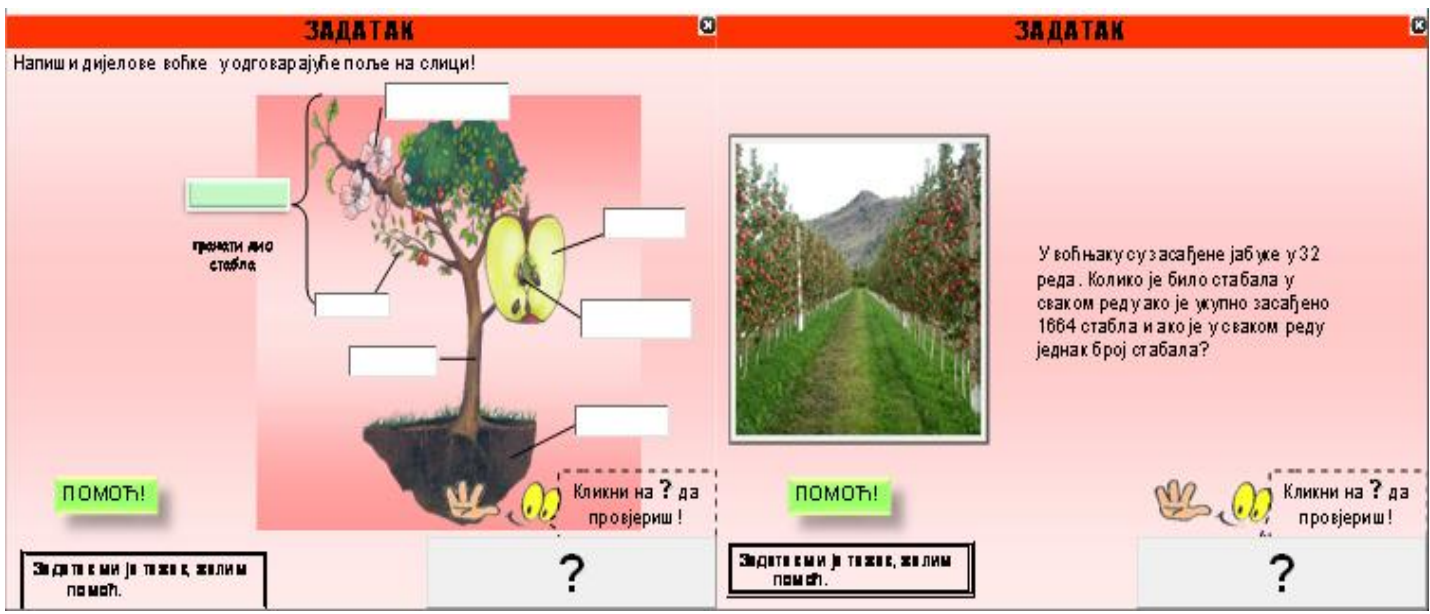

Figure 2. Assessment

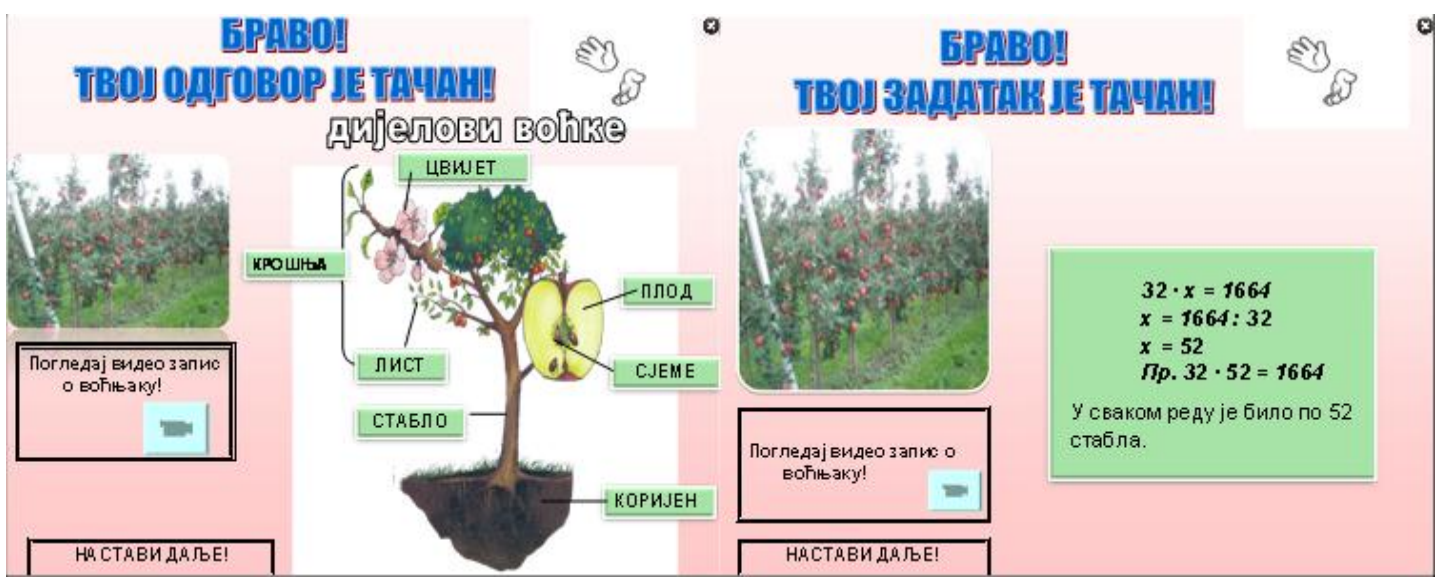

Figure 3. Feedback

$\sqrt{10} 10 \mathrm{~h}$

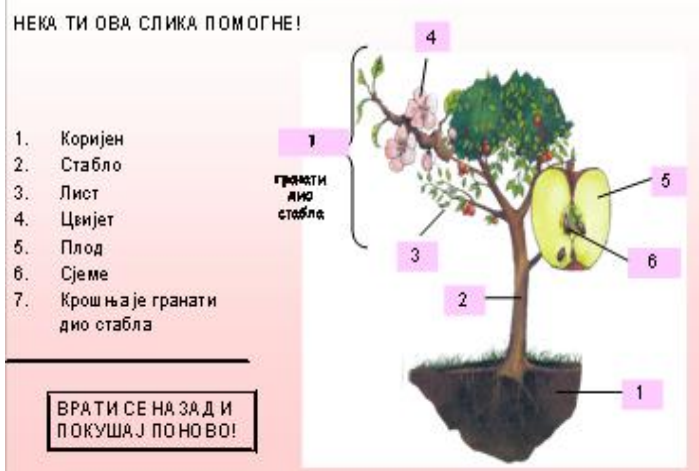

(

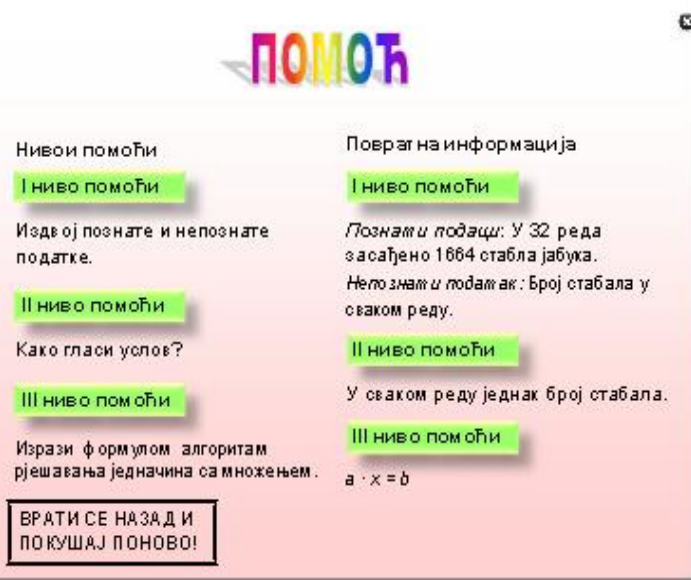

Figure 4. Module of instructions and help in the work

In addition to the shaping of information, the feedback module (Figure 3) also provides an Instruction module, that is, assistance in the work (Figure 4). Given that feedback is provided at each step of learning, it provides the pupil with a timely notification of the accuracy of the solution (real problem and response), the quality of the acquired knowledge, or the level of achievement and correctness of the chosen path.

Help in the work in mathematics has been achieved through the differentiation of the level of assistance (according to Zech, 1999): motivational help, feedback help, general-strategic help, content-oriented strategic help, and content help. 


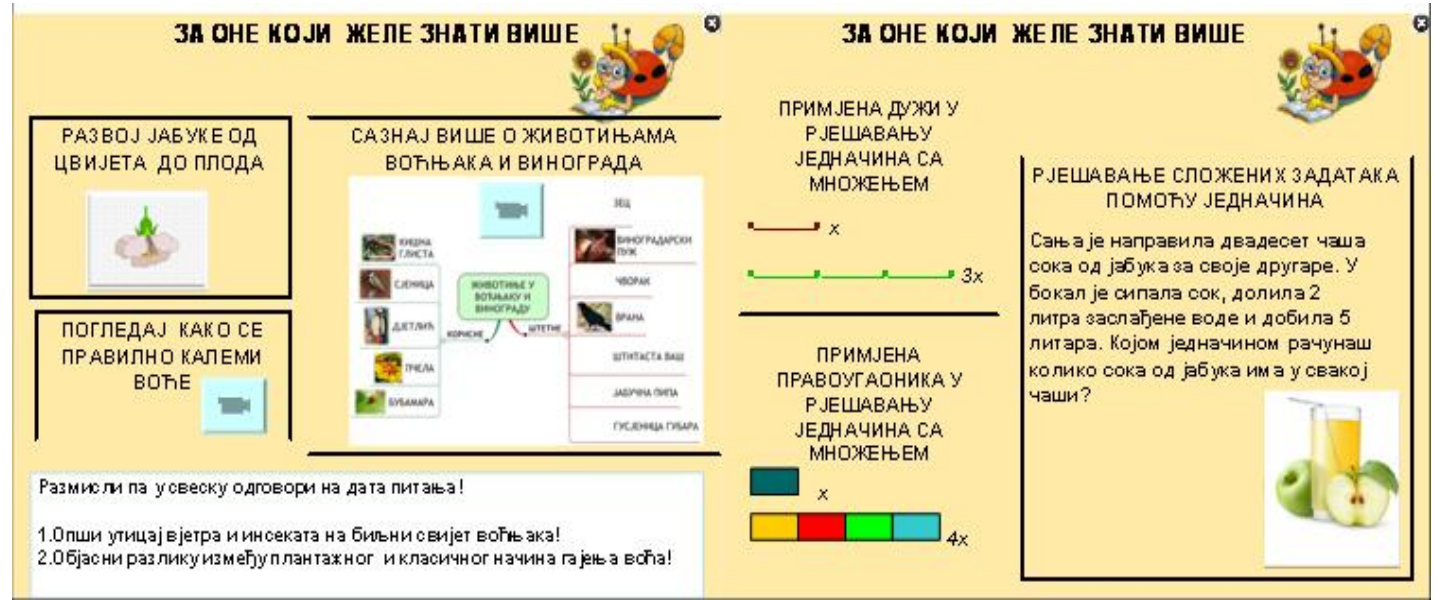

Figure 5. Additional information to expand knowledge

From the point of view of the importance of learning flexibility, for learners who find it difficult or easy to master the material, the module of additional and supplementary information (Figure 5) that encourages the creative potential of pupils is no less important.

Radivojević (2016) emphasized that thanks to such solutions, basic technological, program and organizational prerequisites for successful individualization of teaching work were provided. Unlike the traditional way of learning in which the content and the ways of its adoption are the same for all pupils, the ECS, provides the opportunity for a pupil to determine how many times he will learn and whether he will indeed "visit" certain segments and provide for the application of different techniques of work, learning and solving tasks which correspond to the possibilities and the pace of progress of the individual student. Many researches (Baki \& Çakıroğlu, 2011; Baki, Kösa \& Güven, 2011; Barkatsas, Kasimatis \& Gialamas, 2009; Birgin et al., 2008; Erbas \& Yenmez, 2011; Gübü \& Birgin, 2012; Işıksal \& Aşkar, 2005; Özdemir, Tektaş \& Egelioğlu, 2010; Pilli \& Aksu, 2013; Tabuk, 2003; Tjaden \& Martin, 1995; Tutak \& Birgin, 2008; Ubuz, Ustun \& Erbas, 2009; Qing \& Xin, 2010; Y1ld1z, 2009) according to Birgin, Bozkurt, Gürel and Duru (2015), have proven that computer-assisted teaching has a positive impact on the students' achievements and when it comes to mathematical concepts.

\section{RESEARCH METHODOLOGY}

In the school year 2014/2015 during the second semestar in two elementary schools in Bijeljina (Bosnia and Herzegovina) a research was conducted aimed at examining and experimentally checking the effects of application of the software form of integration and individualization of knowledge of nature and mathematics on content about cultivated habitats and living communities and equations with addition, subtraction, multiplication and distribution in the set $\mathrm{N}$ and $\mathrm{N}_{0}$ and its impact on the quality of knowledge in relation to traditional teaching.

The flow of the experimental part of the study is presented in Scheme $\mathbf{1}$.

Experimental learning model is designed with the intention of influencing the greater unity of the acquired knowledge by linking similar contents in different subjects as a prerequisite for lasting and applicable knowledge in real life situations. During creating the software the objectives and clearly defined learning outcomes to be achieved as well as prior knowledge, skills and abilities of students to whom it is intended have been taken into account. The experiment lasted five weeks as part of regular classes in accordance with the current curriculum of Republic of Srpska (Bosnia and Herzegovina) for the fifth grade in the subjects "Knowledge of Nature" and "Mathematics". In the experimental group during the implementation of teaching subtopics Cultivated habitats and living communities, the contents of Equations with adding, subtracting, multiplying and dividing in the set $\mathrm{N}$ and $N_{0}$ have been integrated.

In the teaching of Knowledge of Nature the contents of the cultivated habitats and living communities (vegetable garden, field, orchard, vineyard, park and flower garden) have been realized. The outcomes have been targeted to gradually discovering the living conditions, the interaction of flora and fauna and the importance of human activities in their interactions within these living communities. 


\begin{tabular}{|c|c|}
\hline \multicolumn{2}{|c|}{$\begin{array}{l}\text { Initial measurement in the E and C group - conducted at the end of January } 2015 . \\
\text { (test with objective type tasks at the beginning of the experiment pedagogical) }\end{array}$} \\
\hline \multicolumn{2}{|l|}{$\downarrow$} \\
\hline \multicolumn{2}{|c|}{$\begin{array}{l}\text { Realization of teaching subtopics cultivated habitats and living communities (Natural Sciences) and equations with adding, } \\
\text { subtracting, multiplying and dividing the set } \mathrm{N} \text { and } \mathrm{N}_{0} \text { (Mathematics) conducted in February, March and April } 2015 .\end{array}$} \\
\hline Experimental group & Control group \\
\hline $\begin{array}{l}\text { Realization of teaching subtopics using educational software } \\
\text { designed for this research. } \\
\text { Within the implementation of teaching subtopics Cultivated } \\
\text { habitats and living communities contents from the topic } \\
\text { Equations with adding, subtracting, multiplying and dividing } \\
\text { the set } N \text { and } N_{0} \text { are integrated. } \\
\text { The classes consisted of a few basic steps: running the } \\
\text { software and opening a teaching unit which is being realized } \\
\text { at the time; adoption of the content section by section in } \\
\text { accordance with personal pace of progress; after each unit } \\
\text { the student has the opportunity to check their knowledge } \\
\text { through a series of questions or tasks; after each step of } \\
\text { checking a student receives feedback on the accuracy of } \\
\text { responses and receives a guidance for the further course of } \\
\text { action; at the end of the class there is a brief discussion and } \\
\text { joint analysis through which the level of mastering the } \\
\text { outcomes and the pupils' achievement has been perceived. }\end{array}$ & $\begin{array}{l}\text { At the same time, the control group implemented the same } \\
\text { contents in a traditional (frontal) way of work and their class } \\
\text { consisted of: introductory motivation; explaining content by a } \\
\text { teacher; exercise, repeating/drills, and student achievement } \\
\text { checks }\end{array}$ \\
\hline \multicolumn{2}{|l|}{ 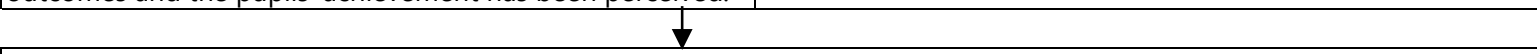 } \\
\hline $\begin{array}{l}\text { The final measure in the } E \text { and } C \\
\text { ast with objective type tasks after }\end{array}$ & $\begin{array}{l}\text { group, realized at the end of April } 2015 . \\
\text { ee implementation of educational research) }\end{array}$ \\
\hline
\end{tabular}

Scheme 1. The flow of experimental research

In the teaching of mathematics the contents of the equations with the addition, subtraction, multiplication and division in the set of $N$ and $N_{0}$ have been realized. The outcomes have been directed to the solution of equations with the addition, subtraction, multiplication and division on the basis of the definition of arithmetic operations in the set $N$ and the set $N_{0}$, and to the tasks given in textual form using the familiar equations.

The experiment was conducted in a computerized classroom where every student practiced individually, based on programmed instructions and instructions for work. In all classes, the teacher had an insight into the work of each student in the software and followed the course of the work, providing assistance in granting courses.

It was begun by basic assumption that the software form of integration and individualization will contribute to a better knowledge both within the analyzed individual cognitive domains (knowledge, understanding and application) and the whole test.

Accordingly, auxiliary hypotheses have been designed:

$\boldsymbol{H}_{1}$ : The experimental group will achieve significantly better results in the final test on each of the analyzed cognitive domains (knowledge, understanding and application) and on the test as a whole, compared to the control group, as a result of the efficiency of application of the software form of integration and individualization of teaching of nature and mathematics education in relation to traditional teaching.

$\mathbf{H}_{2}$ : Experimental group members will, in relation to the control group, achieve greater advancement in mathematics in each of the analyzed cognitive domains (knowledge, understanding and application) and on the test as a whole, because the projected ORS model for mathematics learning in a real context contributes to a higher quality knowledge.

$H_{3}$ : Experimental group boys will achieve much better results in the final test (as in the knowledge of nature as well as in mathematics) on each of the analyzed cognitive domain (knowledge, understanding and application) and in the test as a whole, as compared to the control group, as the result of the efficiency of application of software integration and individualization of teaching of knowledge of nature and mathematics as compared with the traditional approach.

$\boldsymbol{H}_{4}$ : Experimental group girls will achieve much better results in the final test (as in the knowledge of nature as well as in mathematics) on each of the analyzed cognitive domain (knowledge, understanding and application) and in the test as a whole, as compared to the control group, as the result of the efficiency of application of software integration and individualization of teaching of knowledge of nature and mathematics as compared with the traditional approach. 
Table 1. Results of $E$ and $C$ groups in the initial test from Knowledge of Nature

\begin{tabular}{|c|c|c|c|c|c|c|c|}
\hline Cognitive Domains & Group & $\mathbf{N}$ & $\mathbf{M}$ & SD & $\mathbf{t}$ & df & $\mathbf{p}$ \\
\hline \multirow{4}{*}{ Knowledge } & $\mathrm{E}$ & 125 & 18.17 & 3.36 & & & \\
\hline & C & 125 & 17.77 & 3.29 & & & \\
\hline & Total & 250 & 17.97 & 3.33 & .94 & 248 & .34 \\
\hline & $\mathrm{E}$ & 125 & 18.27 & 5.73 & & & \\
\hline \multirow[t]{3}{*}{ Understanding } & $\mathrm{C}$ & 125 & 18.91 & 5.84 & & & \\
\hline & Total & 250 & 18.59 & 5.78 & -.87 & 248 & .38 \\
\hline & $\mathrm{E}$ & 125 & 14.04 & 4.20 & & & \\
\hline \multirow[t]{3}{*}{ Application } & C & 125 & 13.52 & 3.96 & & & \\
\hline & Total & 250 & 13.78 & 4.09 & 1.00 & 248 & .31 \\
\hline & $\mathrm{E}$ & 125 & 50.49 & 11.03 & & & \\
\hline \multirow[t]{2}{*}{ Overall Achievement } & $\mathrm{C}$ & 125 & 50.21 & 10.76 & & & \\
\hline & Total & 250 & 50.36 & 10.88 & .20 & 248 & .83 \\
\hline
\end{tabular}

Table 2. Results of the experimental and control groups at the initial test from Mathematics

\begin{tabular}{|c|c|c|c|c|c|c|c|}
\hline Cognitive Domains & Group & $\mathbf{N}$ & $\mathbf{M}$ & SD & $\mathbf{t}$ & df & $\mathbf{p}$ \\
\hline \multirow{3}{*}{ Knowledge } & $\mathrm{E}$ & 125 & 17.11 & 3.45 & & & \\
\hline & $\mathrm{C}$ & 125 & 16.77 & 3.29 & & & \\
\hline & Total & 250 & 16.94 & 3.37 & .78 & 248 & .43 \\
\hline \multirow{3}{*}{ Understanding } & $\mathrm{E}$ & 125 & 17.09 & 5.74 & & & \\
\hline & $\mathrm{C}$ & 125 & 17.86 & 5.82 & & & \\
\hline & Total & 250 & 17.48 & 5.78 & -1.05 & 248 & .29 \\
\hline \multirow{3}{*}{ Application } & $\mathrm{E}$ & 125 & 13.03 & 4.20 & & & \\
\hline & $C$ & 125 & 12.41 & 4.00 & & & \\
\hline & Total & 250 & 12.72 & 4.10 & 1.18 & 248 & .23 \\
\hline \multirow{3}{*}{ Overall Achievement } & $E$ & 125 & 47.24 & 11.34 & & & \\
\hline & $\mathrm{C}$ & 125 & 47.05 & 10.82 & & & \\
\hline & Total & 250 & 47.14 & 11.06 & .13 & 248 & .89 \\
\hline
\end{tabular}

The survey sample consisted of 250 pupils (eleven grades) of the fifth grade of elementary school (aged 10 to 11 years) from two primary schools in Bosnia and Herzegovina. The pupils were divided into two groups experimental $(\mathrm{N}=125)$ and control $(\mathrm{N}=125)$. The Experimental Group (E) consisted of three classes from one and two classes from another school, while the Control Group (C) consisted of three classes from both schools. The groups were balanced in view of the results achieved on the initial knowledge test from the Knowledge of Nature and Mathematics and the age (from 10 to 11 years).

In terms of the gender of the respondents, in the study participated 132 boys and 118 girls. Based on these data, we notice more boys than girls in both the E group ( 66 boys $-52.80 \%$ and 59 girls $-47.20 \%$ ) and in the C group (66 boys $-52.80 \%$ and 59 girls $-47.20 \%$ ), however, the ratio of the number of boys and girls between $\mathrm{E}$ and $\mathrm{C}$ group is quite balanced.

At the beginning of the research, an initial test was conducted of the knowledge from Knowledge of Nature (Table 1) and Mathematics (Table 2), which established the initial state of independence and knowledge of the pupils needed to conduct the experiment.

The results of the initial knowledge test from the Knowledge of Nature show that E and C group at the beginning of the pedagogical research are well balanced on the basis of pupils previous' previous knowledge. The values of the $\mathrm{t}$-test, in the initial test as a whole $(\mathrm{t}=.20, \mathrm{p}=.83)$, as well as in the individual cognitive domains (knowledge: $\mathrm{t}=.94, \mathrm{p}=.34$; understanding: $\mathrm{t}=-.87, \mathrm{p}=.38$; application: $\mathrm{t}=1.00, \mathrm{p}=.31$ ) are not at the level of statistical significance $\mathrm{p}<.05$, which points to the equality of groups in respect to previously acquired knowledge of Knowledge of Nature.

The results of the initial Mathematics test also confirmed the group's equality at the beginning of the experimental program. Namely, the values of the $t$-test in individual cognitive domains (knowledge: $t=.78, p=.43$; understanding: $\mathrm{t}=-1.05, \mathrm{p}=.29$; application: $\mathrm{t}=1.18, \mathrm{p}=.23)$ and on the whole test $(\mathrm{t}=.13, \mathrm{p}=.89)$, are not at the level of statistical significance $\mathrm{p}<.05$ and clearly indicate that the groups are equal in the initial pre-knowledge in Mathematics.

After the initial testing and equalization of the groups, the implementation of the experimental program was begun, the model of which was designed so that the participants of the experimental group will adopt the contents independently using the projected software form of integration and individualization of teaching of nature and mathematics education, while the students of the control group realize the same contents through the traditional 
Table 3. The importance of differences between group $E$ and $C$ in the final test from Knowledge of Nature (t-test)

\begin{tabular}{|c|c|c|c|c|c|c|c|}
\hline Cognitive Domains & Group & $\mathbf{N}$ & $\mathbf{M}$ & SD & $\mathbf{t}$ & df & $\mathbf{p}$ \\
\hline \multirow{3}{*}{ Knowledge } & $E$ & 125 & 24.56 & 3.88 & & & \\
\hline & C & 125 & 22.32 & 4.57 & & & \\
\hline & Total & 250 & 23.44 & 4.38 & 4.15 & 248 & .00 \\
\hline \multirow{3}{*}{ Understanding } & $E$ & 125 & 23.65 & 6.46 & & & \\
\hline & $\mathrm{C}$ & 125 & 18.95 & 6.71 & & & \\
\hline & Total & 250 & 21.30 & 6.98 & 5.64 & 248 & .00 \\
\hline \multirow{3}{*}{ Application } & $\mathrm{E}$ & 125 & 22.68 & 5.52 & & & \\
\hline & $\mathrm{C}$ & 125 & 15.35 & 5.20 & & & \\
\hline & Total & 250 & 19.02 & 6.49 & 10.79 & 248 & .00 \\
\hline \multirow{3}{*}{ Overall Achievement } & $E$ & 125 & 70.90 & 13.06 & & & \\
\hline & $\mathrm{C}$ & 125 & 56.63 & 13.81 & & & \\
\hline & Total & 250 & 63.76 & 15.20 & 8.39 & 248 & .00 \\
\hline
\end{tabular}

way of work. At the end of the experimental program, the final test tested the level of achievement of E and C group students.

Research Instruments (initial and final test) contain questions and assignments belonging to cognitive domains of knowledge (recognition and memory), understanding and application.

The internal consistency of the tests (initial and final test) was determined according to the reliability of Cronbach alpha coefficient. The values of Cronbach alpha reliability coefficient for the Knowledge of nature for the initial test was .89 and .93 for the final test, while for mathematics and fundamental values of Cronbach alpha for the initial test is .85 and .91 for the final test. Displayed values show that the reliability of the measurements at an acceptable level.

Statistical Processing of data obtained by research was achieved through the software package SPSS 17.0. The statistical parameters were analyzed: mean (M), standard deviation (SD), and $t$-test $(t)$ was used to determine the relationship between two variables with the significance threshold $p=.05$. The results of the research are presented both textually and graphically.

\section{RESULTS AND DISCUSSION}

After the realization of the teaching sub-themes Cultivated habitats and life communities and Equations with addition, subtraction, multiplication and division in the set $N$ and $N_{0}$, using different teaching models, the final exam tested the level of achievement of $\mathrm{E}$ and $\mathrm{C}$ group of pupils and analyzed the justification of the hypothesis. In order to determine whether there are statistically significant differences in the achievement between students of the experimental and control group, both in individual cognitive domains and on the test as a whole, in the situation of the final test, we compared the results of their achievement. We primarily analyzed the results obtained from Knowledge of Nature, and then from Mathematics. In the end, we compared the pupils' success by comparing the arithmetic meanings from both subjects to determine the learning of which the experimental program achieved greater influence.

Table 3 shows the statistical parameters of the final test from Knowledge of Nature as a whole and within individual cognitive domains on which was tested, by calculating the t-test the significance of the differences in the achievement of $\mathrm{E}$ and $\mathrm{C}$ group of pupils.

By analyzing the results we note that there are statistically significant differences in favor of the E group, both on the total final test from Knowledge of Nature, and in all cognitive domains, which is confirmed by the values of the $t$-test with the significance level $p=.00$ for all analyzed parameters. Considering the correspondence value of the $t$-test $(t=1.96)$ for the reliability level $p=.05$, the results of the conducted $t$-test indicate that its values are significantly higher both on the final test as a whole $(t=8.39)$, as well as within individual cognitive domains (knowledge: $t=4.15$; understanding: $t=5.64$ and application: $t=10.79$ ). Since the total number of possible points in the final test was 90 for each individual cognitive domain of 30, Table 3 shows the tendency of the difference where the experimental group has a higher average value on the whole test, which is 70.90, with a standard deviation of 13.06 in relative to the control group with an average value of 56.63 and a standard deviation of 13.81 . In terms of individual cognitive domains, the differences in the average values of the points won are most pronounced in the level of applying the knowledge (E group: 22.68; C group: 15.35), then understanding (E group: 23.65; C group: 18.95) and finally at the level of knowledge E group: 24.56; C group: 22.32), indicating the positive impact of the software integration and individualization capability on the ability to solve complex tasks. 
Table 4. Comparison of students achievement in E and C groups in tests of Knowledge of Nature

\begin{tabular}{lcccc}
\hline Cognitive Domains & Group & N & $\begin{array}{c}\text { Knowledge of Nature Initial } \\
\text { Test }\end{array}$ & $\begin{array}{c}\text { Knowledge of Nature Final } \\
\text { Test }\end{array}$ \\
\hline \multirow{2}{*}{ Knowledge } & E & 125 & 18.17 & 24.56 \\
\hline \multirow{2}{*}{ Understanding } & C & 125 & 17.77 & 22.32 \\
\hline \multirow{2}{*}{ Application } & E & 125 & 18.27 & 23.65 \\
\hline \multirow{2}{*}{ Overall achievement } & $\mathrm{C}$ & 125 & 18.91 & 18.95 \\
\hline & $\mathrm{E}$ & 125 & 14.04 & 22.68 \\
\hline
\end{tabular}

Table 5. The importance of differences between group $E$ and $C$ in the final Mathematics test (t-test)

\begin{tabular}{|c|c|c|c|c|c|c|c|}
\hline Cognitive Domains & Group & $\mathbf{N}$ & $\mathbf{M}$ & SD & $\mathbf{t}$ & df & $\mathbf{p}$ \\
\hline \multirow{3}{*}{ Knowledge } & $E$ & 125 & 24.88 & 3.97 & & & \\
\hline & $C$ & 125 & 21.39 & 4.61 & & & \\
\hline & Total & 250 & 23.14 & 4.63 & 6.42 & 248 & .00 \\
\hline \multirow{3}{*}{ Understanding } & $\mathrm{E}$ & 125 & 22.32 & 6.40 & & & \\
\hline & $C$ & 125 & 16.36 & 6.36 & & & \\
\hline & Total & 250 & 19.34 & 7.03 & 7.38 & 248 & .00 \\
\hline \multirow{3}{*}{ Application } & $\mathrm{E}$ & 125 & 21.72 & 6.01 & & & \\
\hline & $\mathrm{C}$ & 125 & 13.46 & 4.98 & & & \\
\hline & Total & 250 & 17.59 & 6.89 & 11.81 & 248 & .00 \\
\hline \multirow{3}{*}{ Overall achievement } & $\mathrm{E}$ & 125 & 68.92 & 13.64 & & & \\
\hline & $C$ & 125 & 51.21 & 13.26 & & & \\
\hline & Total & 250 & 60.07 & 16.09 & 10.40 & 248 & .00 \\
\hline
\end{tabular}

We then compared the achievements of students in the initial and final test from Knowledge of Nature in order to have a better view of student achievement at the end of the carried out experiment comparing to its beginning (Table 4).

Comparing the results of pupils achievement generated at the initial and final test there is the evident progress achieved by the E group in the final test compared to initial ones. The results of the survey show that the obtained differences in achievements between the pupils of $\mathrm{E}$ and $\mathrm{C}$ group in the final test comparing to the initial one of the Knowledge of Nature is the result of an adequately selected educational content and its effective realization by applying the software form of integration and individualization in the E group in relation to the traditional way of work in the C group.

Such results of work are in accordance with the results of research done by authors who deal with similar issues (Çepni, Tas \& Köse, 2006; Cekić-Jovanović, Golubović-Ilić \& Jakovljević, 2014; Chaudhari, 2013; Hulya Efe \& Rifat Efe, 2011; Serin, 2011; Soleša, 2000; Stanković, 2009; Yusuf \& Afolabi 2010; Županec, Miljanović \& Pribićević, 2013).

In further analysis we tried to determine whether the same effect can be achieved in the realization of the contents in teaching Mathematics.

Table 5 shows the statistical significance of the differences in the success of $\mathrm{E}$ and $\mathrm{C}$ group students in Mathematics at the final test by calculating the t-test.

The values of the $t$-test indicate that there are statistically significant differences in the final mathematical test, both at the total level $(t=10.40, p=.00)$, and within individual cognitive domains (knowledge: $t=6.42, p=.00$; understanding: $t=7.38, p=.00$; application: $t=11.81, p=.00$ ). The tendencies towards differences in favor of the $E$ group are expressed through the average values of the points won. The possible number of points in the final Mathematics test is 90 (for each cognitive domain of 30). At all analyzed levels of knowledge, as well as on the test as a whole, the average value of the points won is in favor of the E group. Differences are, as well as in the teaching of Nature, more pronounced in the achievements of higher cognitive structures, which points to the positive influence of the software form of integration and individualization on the ability to solve complex tasks, which confirms that the software form of integration and individualization results in better quality mathematical knowledge.

In order to introspect the success of students at the end of the carried out experiment in the relation to its beginning we compared students' achievements in the initial and final knowledge test in Mathematics (Table 6). 
Table 6. Comparison of students achievement in $\mathrm{E}$ and $\mathrm{C}$ groups in Mathematics tests

\begin{tabular}{lcccc}
\hline Cognitive Domains & Group & N & $\begin{array}{c}\text { Mathematics } \\
\text { Initial Test }\end{array}$ & $\begin{array}{c}\text { Mathematics } \\
\text { Final Test }\end{array}$ \\
\hline \multirow{2}{*}{ Knowledge } & $\mathrm{E}$ & 125 & 17.11 & 24.88 \\
\hline \multirow{2}{*}{ Understanding } & $\mathrm{C}$ & 125 & 16.77 & 21.39 \\
\hline \multirow{2}{*}{ Application } & $\mathrm{E}$ & 125 & 17.09 & 22.32 \\
\hline \multirow{2}{*}{ Overall achievement } & $\mathrm{C}$ & 125 & 17.86 & 16.36 \\
\cline { 2 - 5 } & $\mathrm{E}$ & 125 & 13.03 & 21.72 \\
\hline
\end{tabular}

After analyzing the results, there is an evident improvement of pupils from E group in the final test in relation to the initial one, both in terms of individual cognitive domains and in the test as a whole. This means that crosscurricular integration with its multiperspective contributes to the development of mathematical thinking.

In the last step of the results of the work analysis we have compared student achievement in individual subjects (Natural Science and Mathematics) based on the results achieved by pupils in the final test of an experimental programme. There is a noticeable improvement in E group students during the experimental research in the final tests of Knowledge of Nature and Mathematics in relation to the $C$ group. The total number of possible points on both tests is 90 , and 30 for each of the cognitive domains. Comparing the average success of pupils of $E$ and $C$ group in the final test (Knowledge of Nature 70.90 and 56.63 points, Mathematics 68.92 and 51.21), we note that the difference in their achievement 14.27 from Knowledge of Nature and 17.71 from Mathematics. When it comes to individual cognitive domains, the differences in achievements between the examinees of $\mathrm{E}$ and $\mathrm{C}$ group are higher at higher levels (knowledge: Knowledge of Nature 2.23, Mathematics 3.49, understanding: Knowledge of Nature 4.70, Mathematics 5.96, application: Knowledge of Nature 7.33, Mathematics 8.25).

The key contribution to the success of the E group has been the application of the software form of integration and individualization in the realized contents of the teaching sub- themes Cultivated habitats and life communities and Equations with addition, subtraction, multiplication and division in the set $N$ and $N_{0}$. Educational computer software is rarely applied in Knowledge of Nature and Mathematics, especially with an interdisciplinary and individualized approach, although the autonomy of work and the integrity of access to teaching content, adapted to the different characteristics of pupils, are key elements of successful teaching. Working independently on software-based content increases pupil activity. Each pupil independently goes through software-supported content, gradually, in accordance with his/her pace and level of knowledge, until he completely overcomes teaching content.

The somewhat greater progress of the E group of mathematicians, both on the final test as a whole and at cognitive levels, is the result of learning mathematics in the context, which primarily strengthens mathematical understanding. "It is understandable, given the growing tendency in the teaching of mathematics, according to which it is not only important that students acquire and master the relevant knowledge, but should be fully equipped to apply knowledge, a critical attitude towards content and an adequate evaluation and in all stages of the teaching process" (Maričić, Špijunović \& Lazić, 2016: 30).

The ways of working in the $\mathrm{C}$ group did not differ from the previous mode of work, and the success of the pupils in the final test, both in terms of achievements on both tests in general as well as in terms of individual cognitive domains, was at a significantly lower level than that of the E group. Pupils of the C group were less motivated to work, less active, less independent and self-motivated, resulting in a lesser success.

These results of the paper in terms of integrative approach with primary school children are in accordance with the results of the research of the authors who have dealt with similar issues (Alghamdi, 2017; Becker \& Park, 2011; Deneme \& Ada, 2012; Duran, Ballone-Duran \& Worch, 2009; Kurt \& Pehlivan, 2013; Milinković, 2012; Tudor, 2014; Ćurčić, Milinković \& Radivojević, 2017).

After all, we have compared student achievement in relation to gender structure. Since the number of boys between the two groups is completely the same ( 66 boys in the E and C group) and girls (in 59 in the E and group C) in order to a better recognition of the success of pupils based on gender we performed a comparative analysis of the results that realized boys, and girls, in the initial and final test for separate subjects.

Table 7 shows the comparative representation of the results which are achieved by boys at the initial and the final test in Knowledge of Nature. 
Table 7. Comparison of boys students achievement in $E$ and $C$ groups in tests of Knowledge of Nature

\begin{tabular}{|c|c|c|c|c|c|c|c|c|c|c|}
\hline \multirow{2}{*}{$\begin{array}{l}\text { Cognitive } \\
\text { Domains }\end{array}$} & \multicolumn{2}{|c|}{ Boys } & \multicolumn{4}{|c|}{$\begin{array}{c}\text { Knowledge of Nature } \\
\text { Initial Test }\end{array}$} & \multicolumn{4}{|c|}{$\begin{array}{c}\text { Knowledge of Nature } \\
\text { Final Test }\end{array}$} \\
\hline & Group & $\mathbf{N}$ & $\mathbf{M}$ & SD & $\mathbf{t}$ & $p$ & $\mathbf{M}$ & SD & $\mathbf{t}$ & $\mathbf{p}$ \\
\hline \multirow{3}{*}{ Knowledge } & $E$ & 66 & 18.24 & 3.25 & & & 23.98 & 3.99 & & \\
\hline & C & 66 & 17.75 & 3.40 & & & 21.57 & 4.00 & & \\
\hline & & & & & $t_{(130)}=.83$ & .40 & & & $t_{(130)}=3.46$ & .00 \\
\hline \multirow{3}{*}{ Understanding } & $\mathrm{E}$ & 66 & 18.54 & 5.80 & & & 22.63 & 6.68 & & \\
\hline & $\mathrm{C}$ & 66 & 19.01 & 5.74 & & & 18.19 & 6.53 & & \\
\hline & & & & & $t_{(130)}=.46$ & .64 & & & $t_{(130)}=3.86$ & .00 \\
\hline \multirow{3}{*}{ Application } & $E$ & 66 & 13.96 & 3.86 & & & 22.28 & 5.56 & & \\
\hline & $\mathrm{C}$ & 66 & 13.30 & 4.07 & & & 15.18 & 4.44 & & \\
\hline & & & & & $t_{(130)}=.96$ & .33 & & & $t_{(130)}=8.10$ & .00 \\
\hline \multirow{3}{*}{$\begin{array}{l}\text { Overall } \\
\text { Achievement }\end{array}$} & $\mathrm{E}$ & 66 & 50.75 & 10.95 & & & 68.90 & 13.32 & & \\
\hline & $C$ & 66 & 50.07 & 10.78 & & & 54.95 & 11.81 & & \\
\hline & & & & & $t_{(130)}=.36$ & .71 & & & $t_{(130)}=6.36$ & .00 \\
\hline
\end{tabular}

Table 8. Comparison of girls students achievement in $E$ and $C$ groups in tests of Knowledge of Nature

\begin{tabular}{|c|c|c|c|c|c|c|c|c|c|c|}
\hline \multirow{2}{*}{$\begin{array}{l}\text { Cognitive } \\
\text { Domains }\end{array}$} & \multicolumn{2}{|c|}{ Girls } & \multicolumn{4}{|c|}{$\begin{array}{c}\text { Knowledge of Nature } \\
\text { Initial Test }\end{array}$} & \multicolumn{4}{|c|}{$\begin{array}{c}\text { Knowledge of Nature } \\
\text { Final Test }\end{array}$} \\
\hline & Group & $\mathbf{N}$ & M & SD & $\mathbf{t}$ & $\mathbf{p}$ & $\mathbf{M}$ & SD & $\mathbf{t}$ & $\mathbf{p}$ \\
\hline \multirow{3}{*}{ Knowledge } & $\mathrm{E}$ & 59 & 18.10 & 3.51 & & & 25.20 & 3.68 & & \\
\hline & C & 59 & 17.79 & 3.20 & & & 23.16 & 5.04 & & \\
\hline & & & & & $t_{(116)}=.49$ & .62 & & & $t_{(116)}=2.50$ & .01 \\
\hline \multirow{3}{*}{ Understanding } & $\mathrm{E}$ & 59 & 17.96 & 5.68 & & & 24.79 & 6.06 & & \\
\hline & C & 59 & 18.79 & 5.99 & & & 19.79 & 6.87 & & \\
\hline & & & & & $t_{(116)}=-.77$ & .44 & & & $t_{(116)}=4.18$ & .00 \\
\hline \multirow{3}{*}{ Application } & $\mathrm{E}$ & 59 & 14.13 & 4.59 & & & 23.13 & 5.50 & & \\
\hline & $C$ & 59 & 13.77 & 3.85 & & & 15.54 & 5.97 & & \\
\hline & & & & & $t_{(116)}=.45$ & .65 & & & $t_{(116)}=7.17$ & .00 \\
\hline \multirow{3}{*}{$\begin{array}{l}\text { Overall } \\
\text { Achievement }\end{array}$} & $\mathrm{E}$ & 59 & 50.20 & 11.22 & & & 73.13 & 12.49 & & \\
\hline & $\mathrm{C}$ & 59 & 50.37 & 10.83 & & & 58.50 & 15.63 & & \\
\hline & & & & & $t_{(116)}=-.08$ & .93 & & & $t_{(116)}=5.61$ & .00 \\
\hline
\end{tabular}

The analysis of the results achieved by E group boys compared to the results which have won C group boys in the initial and the final test of Knowledge of nature shows that boys are equable at the level of statistical significance in the initial test as to the single domains as well as on the test as a whole, while in the final measurement parameters showed statistically significant differences in all analyzed parameters in favor of the boys from the E group.

In the same way the results obtained by the girls in the Knowledge of nature initial and final test have been compared, and the results are shown in Table 8.

The results shown in the table confirm the expectation that in the final test a statistically significant difference in favor of E group girls has been achieved, while in the initial measurement results that have been obtained $\mathrm{E}$ and $\mathrm{C}$ group girls have been uniform at the level of statistical significance. These data are based on the fact that the group $\mathrm{E}$ has been using experimental model of learning in their work and it has contributed to the improved results in terms of $\mathrm{C}$ group, which has been using conventional (traditional) way of work.

Further analysis compared the results achieved by boys and girls in the final test in E group. Girls achieved better results than boys but they are not at the level of statistical significance to the overall level $\left(\mathrm{t}_{(123)}=-1.82, \mathrm{p}=.07\right)$, as well as within individual cognitive domains (knowledge: $\mathrm{t}_{(123)}=-1.76, \mathrm{p}=.08$; understanding: $\mathrm{t}_{(123)}=-1.88, \mathrm{p}=.06$; application: $\mathrm{t}_{(123)}=-8.55, \mathrm{p}=.39$ ), even though the threshold for overall achievement, the level of knowledge and close to the level of understanding of the limit values to be significant at the $p<.05$.

In the same way, we compared the results in Mathematics. Further study shows a comparative review of statistical parameters that are achieved boys in the initial and final Mathematics tests (Table 9).

Results show that boys are uniform at the level of statistical significance in the initial test as for the individual domains and as for the whole test, while in the final measurement E group boys achieved significantly better results than boys in the $C$ group in all analyzed parameters with the level of significance $p=.00$, which is attributable administered the experimental model of learning in the E group.

After that, the results achieved by the girls in the Mathematics tests have been compared, and the results are shown in the Table 10. 
Table 9. Comparison of boys students achievement in $\mathrm{E}$ and $\mathrm{C}$ groups in tests of Mathematics

\begin{tabular}{|c|c|c|c|c|c|c|c|c|c|c|}
\hline \multirow{2}{*}{$\begin{array}{l}\text { Cognitive } \\
\text { Domains }\end{array}$} & \multicolumn{2}{|c|}{ Boys } & \multicolumn{4}{|c|}{$\begin{array}{c}\text { Mathematics } \\
\text { Initial Test }\end{array}$} & \multicolumn{4}{|c|}{$\begin{array}{c}\text { Mathematics } \\
\text { Final Test }\end{array}$} \\
\hline & Group & $\mathbf{N}$ & $M$ & SD & $\mathbf{t}$ & $p$ & $\mathbf{M}$ & SD & $\mathbf{t}$ & $p$ \\
\hline \multirow{3}{*}{ Knowledge } & $\mathrm{E}$ & 66 & 17.18 & 3.26 & & & 24.28 & 4.197 & & \\
\hline & $C$ & 66 & 16.75 & 3.40 & & & 20.40 & 4.223 & & \\
\hline & & & & & $t_{(130)}=.73$ & .46 & & & $t_{(130)}=5.29$ & .00 \\
\hline \multirow{3}{*}{ Understanding } & $E$ & 66 & 17.22 & 5.75 & & & 21.45 & 6.191 & & \\
\hline & $\mathrm{C}$ & 66 & 17.95 & 5.72 & & & 15.53 & 6.062 & & \\
\hline & & & & & $t_{(130)}=-.72$ & .46 & & & $t_{(130)}=5.55$ & .00 \\
\hline \multirow{3}{*}{ Application } & $\mathrm{E}$ & 66 & 12.96 & 3.86 & & & 21.72 & 6.27 & & \\
\hline & $\mathrm{C}$ & 66 & 12.25 & 4.05 & & & 13.43 & 4.38 & & \\
\hline & & & & & $t_{(130)}=1.03$ & .30 & & & $t_{(130)}=8.79$ & .00 \\
\hline \multirow{3}{*}{$\begin{array}{l}\text { Overall } \\
\text { Achievement }\end{array}$} & $\mathrm{E}$ & 66 & 47.37 & 11.15 & & & 67.46 & 13.69 & & \\
\hline & $\mathrm{C}$ & 66 & 46.96 & 10.73 & & & 49.37 & 11.54 & & \\
\hline & & & & & $\mathrm{t}_{(130)}=.21$ & .83 & & & $t_{(130)}=8.20$ & .00 \\
\hline
\end{tabular}

Table 10. Comparison of girls students achievement in $\mathrm{E}$ and $\mathrm{C}$ groups in tests of Mathematics

\begin{tabular}{|c|c|c|c|c|c|c|c|c|c|c|}
\hline \multirow{2}{*}{$\begin{array}{l}\text { Cognitive } \\
\text { Domains }\end{array}$} & \multicolumn{2}{|c|}{ Girls } & \multicolumn{4}{|c|}{$\begin{array}{l}\text { Mathematics } \\
\text { Initial Test }\end{array}$} & \multicolumn{4}{|c|}{$\begin{array}{l}\text { Mathematics } \\
\text { Final Test }\end{array}$} \\
\hline & Group & $\mathbf{N}$ & $\mathbf{M}$ & SD & $\mathbf{t}$ & $\mathbf{p}$ & $\mathbf{M}$ & SD & $\mathbf{t}$ & $\mathbf{p}$ \\
\hline \multirow{3}{*}{ Knowledge } & $\mathrm{E}$ & 59 & 17.03 & 3.69 & & & 25.55 & 3.62 & & \\
\hline & $C$ & 59 & 16.79 & 3.20 & & & 22.49 & 4.81 & & \\
\hline & & & & & $\mathrm{t}_{(116)}=.37$ & .71 & & & $t_{(116)}=3.91$ & .00 \\
\hline \multirow{3}{*}{ Understanding } & $\mathrm{E}$ & 59 & 16.94 & 5.77 & & & 23.28 & 6.53 & & \\
\hline & $\mathrm{C}$ & 59 & 17.76 & 5.97 & & & 17.28 & 6.60 & & \\
\hline & & & & & $t_{(116)}=-.75$ & .45 & & & $t_{(116)}=4.95$ & .00 \\
\hline \multirow{3}{*}{ Application } & $E$ & 59 & 13.10 & 4.59 & & & 21.71 & 5.76 & & \\
\hline & $C$ & 59 & 12.59 & 3.96 & & & 13.49 & 5.62 & & \\
\hline & & & & & $t_{(116)}=.64$ & .52 & & & $t_{(116)}=7.84$ & .00 \\
\hline \multirow{3}{*}{$\begin{array}{l}\text { Overall } \\
\text { Achievement }\end{array}$} & $E$ & 59 & 47.08 & 11.64 & & & 70.55 & 13.52 & & \\
\hline & $\mathrm{C}$ & 59 & 47.15 & 11.02 & & & 53.27 & 14.79 & & \\
\hline & & & & & $t_{(116)}=-.03$ & .97 & & & $t_{(116)}=6.62$ & .00 \\
\hline
\end{tabular}

The given data indicate that in the initial measurement of girls there is no statistically significant difference, which is to be expected because the groups are uniform, but in the final measurement statistically significant differences are achieved in favour of E group girls.

By comparing the results between boys and girls in the final test group we can notice that the boys won a slightly higher score in the second level of knowledge (application) while girls achieved slightly higher number of points in the other parameters, although none of them were at the level of statistical significance (knowledge: $t_{(123)}=-1.80$, $\mathrm{p}=.07$; understanding: $\mathrm{t}_{(123)}=-1.60, \mathrm{p}=.11$; application: $\mathrm{t}_{(123)}=-.14, \mathrm{p}=.98$; overall achievement $\left.\mathrm{t}_{(123)}=-1.26, \mathrm{p}=.20\right)$.

Summarizing the overall results, we can conclude that, by introducing the experimental factor, by applying the software form of integration and individualization in the realized contents, the pupils of the E group achieved knowledge that was in general much better, of better quality and longer lasting, as well as within the analyzed cognitive domains (knowledge, understanding and application) thus justifying research hypotheses.

\section{CONCLUSIONS}

This work presents a contribution to the foundation of contemporary, integrated and individualized teaching of nature and mathematics, supported by educational computer software. The learning strategies that are initiated by it require that students actively engage in the teaching process, learn Mathematics and "Knowledge of Nature" by discovering that mathematical knowledge and skills are acquired in a natural context. Ćurčić, Milinković and Radivojević (2017) point out that such a way contributes to the activation of the teaching process, because various types of activities and related contents of various subjects and teaching topics that are in line with students' interests are provided for their more active participation in the realization of the content. This creates the conditions and creates opportunities for expressing the specific potentials that pupils have, provides opportunities for better ideas, new interests and achievement of success, regardless of the differences in the level of adoption of knowledge that exist among children. 
Based on the analyzed, empirically exact data, we can conclude that the projected model of the software form of integration and individualization justified the positive and affirmative expectations of its impact on the success of pupils in the process of teaching Knowledge of Nature and Mathematics, and that it can be accepted as a desirable model of teaching and learning.

It is just a link in the chain of many positive features that can be associated with teaching with educational computer software, which is based on encouraging the complete training of an individual to successfully deal with the flows of modern society.

Regardless of the numerous advantages of multimedia and their high flexibility, it should be pointed out that the quality, the level of achievement of the individual and collective educational achievement depends on the quality of the previously programmed material, the chosen methodical approach and the organization of their multimedia presentation. Their rational application implies innovation of key phases and teaching elements, as well as the transformation of the position and role of not only pupils, but also other participants in the entire educational process.

\section{REFERENCES}

Alghamdi, A. K. H. (2017). The Effects of an Integrated Curriculum on Student Achievement in Saudi Arabia. EURASIA Journal of Mathematics Science and Technology Education, 13(9), 6079-6100. https:/ / doi.org/10.12973/eurasia.2017.01051a

Becker, K., \& Park, K. (2011). Effects of integrative approaches among science, technology, engineering, and mathematics (STEM) subjects on students' learning: A preliminary meta-analysis. Journal of STEM Education: Innovations and Research, 12(5/6), 23-37.

Birgin, O., Bozkurt, E., Gürel, R., \& Duru, A. (2015). The Effect of Computer-Assisted Instruction on 7th Grade Students' Achievement and Attitudes toward Mathematics: The Case of the Topic "Vertical Circular Cylinder". Croatian Journal of Education, 17(3), 783-813. https:// doi.org/10.15516/cje.v17i3.1075 Retrieved from http:/ / cje2.ufzg.hr/ojs/index.php/CJOE/article/view/1075/498

Cekić-Jovanović, O., Golubović-Ilić, I., \& Jakovljević, A. (2014). Stavovi i mišljenja učenika o učenju Prirode i društva primenom obrazovno-računarskog softvera sa multimedijalnim sadržajima. Uzdanica, IX(1), 141158.

Çepni, S., Tas, E. \& Köse, S. (2006). The effects of computer-assisted material on students' cognitive levels, misconceptions and attitudes towards science. Computers $\mathcal{E}$ Education, 46(2006), 192-205. https://doi.org/10.1016/j.compedu.2004.07.008 Retrieved from http:/ / citeseerx.ist.psu.edu/viewdoc/ download?doi=10.1.1.567.2985\&rep=rep1\&type=pdf

Chaudhari, P. (2013). Computer Assisted Instruction (CAI): Development of instructional Strategy for Biology Teaching. Educationia Confab, 2(1), 106-116. Retrived from http://www.academia.edu/3318237/Computer_Assisted_Instruction_CAI_Development_of_instructiona 1_Strategy_for_Biology_Teaching

Ćurčić, M. (2006). Metodička i organizaciona struktura nastave prirode i društva. Istočno Sarajevo: Zavod za udžbenike i nastavna sredstva.

Ćurčić, M., Milinković, D., \& Radivojević, D. (2017). The Effects of Integrating Mathematics and Science \& Social Studies Teaching in Learning Mathematics (Eds.), Proceedings of INTCESS 2017 th International Conference on Education and Social Sciences (pp. 575-584). Istanbul: OCERINT, International Organization Center of Academic Research Retrived from http:/ /ijaedu.ocerintjournals.org/download/article-file/298534

Deneme, S., \& Ada, S. (2012). On applying the interdisciplinary approach in primary schools. Procedia - Social and Behavioral Sciences, 46, 885-889. https://doi.org/10.1016/j.sbspro.2012.05.217

Duran, E., Ballone-Duran, L., \& Worch, E. A. (2009). Papier-mâché animals: An integrating theme for elementary classrooms. The Science Education Review, 8.

Efe, H. A., \& Efe, R. (2011). Evaluating the effect of computer simulations on secondary biology instruction: An application of Bloom's taxonomy. Scientific Research and Essays, 6(10), 2137-2146. https://doi.org/10.5897/SRE10.1025 Retrieved from http://www.academicjournals.org/article/article1380713481_Efe\%20and\%20Efe.pdf

Furner, J. M., \& Kumar, D. D. (2007). The Mathematics and Science Integration Argument: A Stand for Teacher Education. EURASIA Journal of Mathematics, Science and Technology Education, 3(3), 185-189. https:/ / doi.org/10.12973/ejmste/75397

Grdinić, B., \& Branković, N. (2005). Metodika poznavanja prirode i sveta oko nas u nastavnoj praksi. Bački Petrovac: „Kultura”. 
Jacobs, H. H. (1989). Interdisciplinary curriculum: Design and implementation. Alexandria, VA: Association for Supervision and Curriculum Development.

Kurt, K., \& Pehlivan, M. (2013). Integrated programs for science and mathematics: review of related literature. International Journal of Education in Mathematics, Science and Technology, 1(2), 116-121. Retrieved from http:/ /ijemst.com/issues/1_2_5_Kurt_Pehlivan.pdf

Lambić, D. (2014). Factors Influencing Future Teachers' Adoption of Educational Software Use in Classroom. Croatian Journal of Education, 16(3), 815-846. Retrieved from https:/ / hrcak.srce.hr/128200

Maričić, S., Špijunović, K., \& Lazić, B. (2016). The Influence of Content on the Development of Students' Critical Thinking in the Initial Teaching of Mathematics. Croatian Journal of Education, 18(1), 11-40. https://doi.org/10.15516/cje.v18i1.1325 Retrived from https://hrcak.srce.hr/155469

Mayer, R. E. (2009). Multimedia learning (2nd ed). New York: Cambridge University Press. https://doi.org/10.1017/CBO9780511811678

Milinković, D. (2012). Integrative Approach to Teaching Mathematics in the Republic of Srpska."Theory and Practice of Connecting and Learning Process", proceedings. Sombor: University of Novi Sad Faculty of Education in Sombor.

Milinković, D. (2013). Interdisciplinarni problemski pristup obradi matematičkih sadržaja u mlađim razredima osnovne škole. Nova škola, 11-2013, 167-175. https:/ / doi.org/10.7251/HCK1311124M

Milinković, D., \& Pikula, M. (2013). Uloga priče i slike u integrisanju početne nastave matematike i srpskog jezika (Eds.), Nastava i učenje - kvalitet vaspitno-obrazovnog procesa (pp. 417-430). Užice: Univerzitet u Kragujevcu Učiteljski fakultet u Užicu.

Milinković, D., \& Pikula, M. (2014). Problemi nastave matematike bazičnog školskog ciklusa (Eds.), Nastava i učenje - savremeni pristupi i perspektive (pp. 555-568). Užice: Univerzitet u Kragujevcu Učiteljski fakultet u Užicu.

Milinković, J. (2011). Elementi integrativnog pristupa u udžbenicima. Inovacije u nastavi, 11(1), 53-63.

Pešikan, A., \& Ivić, I. (2000). Interaktivna nastava - aktivno učenje kao vid osavremenjivanja nastave. Nastava $i$ vaspitanje, XLIX(1-2), 160-172.

Radivojević, D. (2016). Obrazovni računarski softver u nastavi prirode i društva. Bijeljinski metodički časopis, 3(2016), 24-30.

Republika Srpska, Ministarstvo prosvjete i kulture \& Pedagoški zavod (2014). Natavni plan i program za osnovnu školu. Istočno Sarajevo: Zavod za udžbenike i nastavna sredstva.

Rodić, N. (2014). Connection Between Physical Education and Other School Subjects in Primary School. Croatian Journal of Education, 16(3), 265-292. Retrived from http:/ / hrcak.srce.hr/129532

Serin, O. (2011). The Effects of the Computer-Based Instruction on the Achievement and Problem Solving Skills of the Science and Technology Students. The Turkish Online Journal of Educational Technology (TOJET), 10(1), 183-201. Retrieved from http:/ / kisi.deu.edu.tr/oguz.serin/2011.yili.makaleler/tojet.2011.pdf

Soleša, D. (2000). Obrazovna tehnologija u individualizovanoj i diferenciranoj nastavi (Eds.), Diferencijacija $i$ individualizacija nastave - osnova škole budućnosti (pp. 187-204 ). Sombor: Učiteljski fakultet.

Stanković, D. (2009). Interaktivni elektronski izvori informacija u funkciji podizanja kvaliteta nastave prirode i društva. Inovacije u nastavi, 12(3), 51-56.

Tudor, L. (2017). Primary school skills development through integrated activities. Procedia - Social and Behavioral Sciences, 127, 722-727. https:/ / doi.org/10.1016/j.sbspro.2014.03.343

Walsh, B. K. (2002). Kurikulum za proi razred osnovne škole: stvaranje razreda usmjerenog na dijete. Zagreb: Pučko otvoreno učilište Korak po korak.

Yusuf, M. O., \& Afolabi, A., O. (2010). Effects of Computer Assisted Instruction (CAI) on Secondary School Students' Performance in Biology. Turkish Online Journal of Educational Technology (TOJET), 9(1), 62-69. Retrieved from http:/ / files.eric.ed.gov/fulltext/EJ875764.pdf

Zech, F. (1999). Grundkurs Mathematikdidaktik - Theoretische und praktische Anleitungen für das Lehren und Lernen von Mathematik. Weinheim und Basel: Beltz Verlag.

Županec, V., Miljanović, T. \& Pribićević, T. (2013). Effectiveness of Computer-Assisted Learning in Biology Teaching in Primary Schools in Serbia. Journal of the Institute for Educational Research, 45 (2), 422-444. https://doi.org/10.2298/ZIPI1302422Z Retrieved from http:/ / www.ipisr.org.rs/Upload/Dokumenta/Strane/Vera\%20Zupanec,\%20Tomka\%20Miljanovic,\%20Ti jana \%20Pribicevic.pdf

\section{http://www.ejmste.com}

